ljtihad: Jurnal Wacana Hukum Islam dan Kemanusiaan

Vol. 20, No. 2 (2020), pp. 211-234, doi : 10.18326/ijthad.v20i2.211-234

\title{
Fairness in the distribution of land ownership in Indonesia based on Islamic law perspective
}

\section{Koko Komaruddin}

Universitas Islam Negeri (UIN) Sunan Gunung Djati Bandung

E-mail:koko.komaruddin@uinsgd.ac.id

DOI: 10.18326/ijtihad.v20i2.211-234

The imbalance of land ownership and tenure, which results in several land cases, becomes the main problem in agrarian sector in Indonesia that needs quick handling. Although the government has issued some policies related to the agrarian sector, such cases have not been completely solved. The main cause of the imbalance of land ownership is not merely about substance or policy related to land, but also the fundamental concept, philosophy, and orientation of the policy. Regarding this matter, this article explains Islamic point of view about fairness in distribution of land ownership as an alternative solution. Methodologically, this research is normative juridical research which is not only descriptive, but also prescriptive with doctrinal approach. According to a research conducted, every policy related to land issued by the government should be based on the principles of public interest or social justice as well as security of life and property, which become part of the concept of maqa>shid al-syari'ah. Thus, the government must play an active role in the mechanism for the distribution and revocation of property rights over the land. Additionally, to make a fair and equitable the distribution of land, the government is required to provide supports, such as intensification and extensification so that all people are able to receive, manage, and use land ownership rights.

Ketimpangan pemilikan dan penguasaan tanah, yang menimbulkan berbagai kasus pertanahan merupakan persoalan pokok bidang pertanahan di Indonesia yang harus segera diatasi. Meskipun pemerintah telah menerbitkan berbagai kebijakan terkait dengan pertanahan, namun ternyata persoalan tersebut belum dapat diselesaikan secara tuntas. Penyebab utama dari persoalan ketimpangan pemilikan tanah bukan sekadar soal substansi atau materi kebijakan tentang pertanahan, melainkan lebih pada konsep dasar, filosofi, dan orientasi kebijakan tersebut. Sehubungan dengan ini, artikel ini menguraikan pandangan hukum Islam tentang keadilan distribusi pemilikan tanah sebagai solusi alternatif. Secara metodologis, penelitian ini merupakan penelitian yuridis normatif yang tidak hanya 
bersifat deskriptif, tetapi juga bersifat preskriptif dengan pendekatan doktrinal. Berdasarkan penelitian yang telah dilakukan, setiap kebijakan tentang pertanahan yang hendak dikeluarkan pemerintah harus berlandaskan pada prinsip kemaslahatan umum atau keadilan sosial, prinsip pemeliharaan jiwa, dan harta, yang merupakan bagian dari konsep maqāsid al-syariah. Untuk hal tersebut, pemerintah harus berperan aktif dalam mekanisme pembagian dan pencabutan hak milik atas tanah. Selain itu, agar pendistribusian tanah berjalan dengan adil dan merata, pemerintah diharuskan memberikan bantuanbantuan lain, seperti intensifikasi dan ekstensifikasi, sehingga setiap rakyat telah siap dan mampu untuk menerima hak pemilikan tanah, untuk kemudian mengelola dan memanfaatkannya.

Keywords: fairness; land ownership; Islamic law.

\section{Introduction}

Since the beginning of Indonesian independence, the awareness of the importance of land for people has motivated the state (the government) to make a special regulation on land, included in Article 33 paragraph 3 of 1945 Indonesian Constitution. The article states that "the land, the waters, and the natural resources within shall be under the power of the state and shall be used to the greatest benefit of the people". After then, the government issued the Indonesian Constitution No.5 of 1960 concerning on Basic Agrarian Law as the basic constitution regarding land matter (Syarief, 2012: 2). These two basic constitutions, especially the Basic Agrarian Law, in certain limit, have changed the concept of rationale and foundation of colonial agrarian politics that is feudalistic, capitalistic, and liberalistic into populist (Rachman and Setiawan, 2015: 1).

Furthermore, the Basic Agrarian law has replaced the colonial land order that more focuses on foreign capital interest by the national land order that more focuses on public interest. It is applied as lex generalis. One of the important parts of the Basic Agrarian Law is the provision related to land ownership and tenure (Article 7 of the Basic Agrarian Law). To accommodate the provision further, Lex Specialis is issued in the form of the Government Regulation of Constitution Replacement Number 56 of 1960 concerning on the Determination of Farm Land Area known as Landreform Constitution, and the Government Regulation Number 224 of 1961 (PP 224/1961) concerning of the Implementation of Land Distribution and Compensation (Yubaidi, 2019: 712-720).

Nevertheless, the existence of the various rules does not guarantee effectiveness in the implementation. In fact, inequality and imbalance of land ownership and tenure are the 
main problems of land in Indonesia that still exist and have not been resolved. The issue of inequality and the imbalance of land ownership and tenure in Indonesia are triggered by the expansion of capitalism, both "horizontal expansion" and "vertical expansion". Two expansions of capitalism are interwoven with, and lead to the policies of the state apparatus (Stewart in Shorrocks, 2005: 102; Nurjannah, 2014: 193-205; Shohibuddin, 2019: $1-12$;). In this paper, operationally, horizontal expansion is interpreted by the expansion of capitalism as consequence of competition, contestation, and the dominance of ownership, tenure, use, and land use among the people. Meanwhile, vertical expansion is interpreted as an expansion of capitalism that occurs as the result of government (state) support to conglomerates/corporations, both through land granting and identification. In turn, the horizontal expansion of capitalism raises inequality between classes, and the vertical expansion of capitalism triggers inequality between sectors. Inter-class inequality is inequality in terms of land ownership and tenure in the agricultural sector, while intersectoral inequality is inequality in the allocation of land between those intended for farming and for conglomerate/corporate businesses. There are some examples of the practice of capitalism expansion, namely: the provision of vast tracts of land for conglomerates/ corporations that causes an accumulation of land ownership and tenure; the provisions obtaining an understanding that land is a commodity, so it ignores other values, such as religious values (Article 2 of the Basic Agrarian Law) and social function of land (Article 6 of the Basic Agrarian Law); and regulations that provide opportunities for land acquisition for development purposes.

Besides the issues of inequality and imbalance, land issues in Indonesia are covered by various land cases, such as conflicts, disputes, and land cases, between the state (the government), conglomerates/corporations (private), and the people (Simanjuntak, 2017: 171-188). In this context, various land cases are resolved through the General and State Administrative Court. However, the settlement of various cases that enter the judicial agencies is largely resolved with unsatisfactory results, such as conflicting decisions on the same land case. Furthermore, based on the data from the National Land Agency (BPN), throughout 2010 until 2019, the number of land cases generally decreases. In detail, at the end of 2010, there were 12,267 thousand cases of land, while in January 2011 to June 2011, 
only about 1,337 of 14,337 land cases were resolved, so that there were 13,000 cases of land disputes in Indonesia that had not been resolved.

These facts, indirectly, show disharmony either between the mandate and goals of the 1945 Constitution and UUPA 1960 (the Basic Agrarian Law) with the elaboration in the implementing law or between all laws and regulations with the implementation in the field. According to agrarian reform consortium (Konsorsium Pembaruan Agraria/KPA), several land cases have led to violence, persecution, and criminalization, both against farmers and activists. Regarding this matter, it can be stated that land law in Indonesia fails to provide solution for resolving various land issues because of its complex, inconsistent, fragmented, and unfair characteristics, which is not in line with reality in the field (Bedner in McCarthy and Robinson, 2016: 241). Moreover, the dualism of inter-ministerial administration, namely between the Ministry of Agrarian and Spatial Planning/National Land Agency and the Ministry of Environment and Forestry, also becomes an obstacle to create fairness and the balance of land distribution to the people (Neilson, 2016: 254).

Regarding the sources of agrarian law applied in Indonesia, article 5 of the Basic Agrarian Lawstates that the main source of agrarian law especially about land in Indonesia, is customary law under the condition of having no conflict with the national and state interests; based on national unity and Indonesian socialism; in accordance with the existing regulations; and relying on the elements of religious law. This article implies that there are religious communalistic elements in agrarian or land law in Indonesia. However, in reality, the role of religious elements or religious law, especially Islamic law, has not yet appeared significantly. The provisions of Article 5 of the Basic Agrarian Law are a warning to legislators to pay attention to the elements that rely on religious law in developing and establishing the national land law. Related to that matter, it can be said that Islamic law has a great potential for the development and the formation of national law on land sector. This is based on the theory of the existence of law and the position of Islamic law in the national legal system. It can serve as several forms, namely existence as an integral part of Indonesian national law; existence in the sense of independence, strength, and authority recognized and given status as national law; existence in the sense of religious legal norms that serve as a filter for the ingredients of Indonesian national law; and existence as the 
main element of Indonesian national law (Ichtijanto in Arif, 1991: 137).

Based the above theory and Article 5 of the Basic Agrarian Law, the position of Islamic law in Indonesian land law is a legal norm that functions to filter out the national law on land, namely customary law. In fact, it is possible to make Islamic law as the main element of Indonesian land law as long as it follows the rules applied by the constitution. This argument is based on the historical fact that Indonesia, as a nation state religion, has accommodated juridical-constitutional Islamic law through legislative procedures and political processes. The accommodation of the state toward the implementation of Islamic law can be seen from the issuance of legislation that becomes a direct product of Islamic law through legislation and political processes, starting from the Law on Marriage to the Law on Islamic Banking. In the context of land ownership, as Ridwan (2019: 164171) argued, Islam has laid the foundations of agrarian law reform or land reform, from the oppressive and exploitative pre-Islamic system of land ownership towards the fair, equitable and humanist-religious-based distribution of land ownership.

Islamic law, as the main element of Indonesian land law, seems to be prospective as viewed from its fairness perspective. The fairness of Islamic law about the concept of agrarian can be traced from the essence of Islamic teachings, both in the form of general principles, such as texts, the empirical history of Islamic society, and the consideration of maqäsid al-syari'ah as well as the specific principles, such as the concepts of iqthä' and bima'. One of the verses of Koran related to the issue of fairness in the distribution of assets ownership including land is Surah Al-Hasyr verse 7, that states

"Any spoils (fai) that Allah gave to His Messenger (of assets) that came from the population cities, then are for God, for the Prophets, relatives, orphans, the poor and those who are on the way, so that the assets do not circulate among the rich only, among you ..."

Moreover, fairness in the distribution of land ownership can also be analyzed in terms of the concept of maquasid al-syari'ah and iqthä. By implementing the concept of maqasid alsyari'ah, it can be seen the position of land as a source of needs for human life and its scope in five main elements of life, so that the regulation can be considered carefully according to fairness, benefit, and human prosperity. Meanwhile, more practically, the concept of $i q t h \vec{a}$ can determine strategic and tactical steps when dealing with issues of inequality and 
imbalance of land ownership. Simply, iqthä' can be understood as giving land to the people carried out directly by the state.

Based on the various considerations above, this paper will explore the concept of Islamic law fairness regarding agrarian and its relevance to the distribution of land ownership in Indonesia. For this purpose, the author will examine several texts in the Koran, and the ideas of Islamic law experts relevant to the topic discussed in this paper. Methodologically, thus, this research is normative juridical which is not only descriptive, but also prescriptive. This research is approached with a doctrinal approach to explain the concept of Islamic Land Law and the fairness in the distribution of land ownership in Indonesia. Systematically, this paper discusses the normative review of the doctrine of Islamic fairness, the concept of Islamic land law which covers the principles of Islamic economics, the principles of Islamic law and the position of land and assets in the view of Islamic law, and the review of maqāsid al-syari'ah, and other instruments, such as the concept of iqthäas the basis of legislation and alternative mechanism for the distribution of equitable land ownership.

\section{Discourse of fairness in the distribution in Islamic perspective}

Etymologically, fairness in Arabic can be interpreted by straightening or sitting straight; escape, depart or evade the wrong path to the right path; equal or equalizing; balance or compensate for, equal or in a balanced state (Khadduri, 1984: 8). According to alAsfahani, if viewed from an infinitive form (mashdar), then the meaning of fairness can be understood into two, namely showing something that is only captured by reason, for example fairness in the field of law, and showing something captured by the senses, for example fairness in the scales, size, and count (al-Ashfahani, 2004: 336). In more detail, the meaning of fairness can be formulated into four meanings, namely fairness as equality, fairness as a balanced condition that is identical to conformity or proportionality, fairnessas a concern for individual rights and giving the rights to the owner, and fairnessas the way of maintaining the right of the continuity of existence ascribed to God (Shihab, 1996: 114116; Muthahhari, 2009: 60-69).

In another view, it is stated that the term fairness derived from the words al-' adl, al-qisth, and al-wasath have functional meanings. More specifically, the word $a l$-'adl means an attitude 
that emphasizes liver function (psychic), the word al-qisth emphasizes the function of division (physical), and al-wasath is understood as the nature of fairness itself which means equal or balanced (Tasmara, 2001: 152). The functional meanings of the term fairness provide an understanding that fairness is an attitude and effort to equate and to balance which include inner and outer aspects, which must be upheld in human life. From here, if it is related to the context of the nation and the state, fairness in its psychological function is relevant to the duties, principles, and functions of judges in judicial bodies, while fairness in its physical functions can be in the form of legal materials issued by the government and binding on every citizen country.

Fairness, in the perspective of Islamic law, is not just positive justice in the form of human product concepts formulated based on individual and collective interests, but also revelational justice that comes from God. Although fairness is derived from God, namely from the text of the Koran and hadith (two main sources of Islamic teachings), but fairness applies to all humanity. This is because fairness is a universal and unchanging religious teaching, so it can be applied in every aspect of human life, with the aim of developing its potential for life, without distinguishing ethnicity, religion, race, class, and social status (al-Zuhaili, 1991: 41).

In addition to the description of the meanings above, the term fairness from the words al-' $a d l$ and al-qisth also implies fair distribution, including the distribution of sources of human life. From this meaning, Ali Engineer (1990: 51) states that capital accumulation is permitted to the extent that it is in the broad interest (general) and is not intended for the personal interest or the few people. While for Haidar Naqvi (1994: 110), distribution justice will always be intertwined with true social conditions. The purpose of a true social situation is a condition that prioritizes the rationality characterized by a high level of income (wealth) alignment in the social system. This can be realized through a distribution of income and wealth in accordance with the norms of rationality and universally accepted. According to Mahfooz Ahmad (1982: 311), the fair distribution and the true social conditions can only be realized when there is a guarantee of certainty and equal opportunity for everyone to strive for their needs according to the limits of reasonableness. In this context, fairness in the distribution in an effort to realize a true social situation must be flexible in a fundamental 
policy framework. Therefore, at the state level, the government holds highest authority is required to make regulations that do not favor a particular group or group so that the distribution process can be carried out fairly and widely felt. On this basis, it can be assumed that economic justice and social justice cannot be realized without legal justice.

Nowadays, fairness can be likened to an oasis in a human life. Fairness, both in a community and a state, is the dream in a human life that aims to diminish inequality and imbalance on the sources of livelihood. Every aspect or sector of life, such as in economic, legal, political, and social aspects, always makes fairness the main principle. In a review of Islamic legal philosophy, fairness is considered as one or even the sole purpose of making legislation (Auda, 2008: 21-22). On the central position in the law, it is common that fairness can only be understood when it is positioned as a condition thatis intentionally realized by the law. By prioritizing the principle of fairness in various aspects, the transformation of life and decent livelihood can be realized and harmonious relationshipamong people will always be maintained.

\section{The concept of land law in Islam}

In the Land Law of the Republic of Indonesia, it is explained that agrarian is matters related to registration, provision, use, tenure, and cultivation of land, as well as any activities on land, which is regulated by the land law. Since it is still in planning stage, the land law applied in Indonesia until now is the Basic Agrarian Law 1960 is lex generalis and any operational constitution as lex specialis. However, as already mentioned before, the existence of these rules has not resolved land issues. Therefore, this section explains the concept of Islamic land law as an input or reference to land issues in Indonesia.

If borrowing and slightly modifying the opinion of Qodri Azizy (2004: 41), then the term Islamic agrarian referred to in this paper is to reveal the characteristics of Islamic law in the form of continuous training/thinking regarding agrarian described according to Islam. Thus, the desired emphasis of this term is that the matter examined in this paper is the result of thinking about the land sector based on the framework of Islamic law. Islamic land law itself appears as the result of ownership, tenure, use, and utilization of land. Conceptually, Islamic land law can be understood as Islamic law about land regarding the 
ownership (milkiyah), cultivation (tasharruf), and distribution (tauri) (Mahasari, 2008: 39). In general, the fuqaha or jurisprudence names the land law as abkam al-aradhi, and many of them discuss it from the point of view of economy, especially about property management (al-amwâh), or from the perspective of Islamic state order law. In this context, Islamic land law will always be related to and not separated from economic and constitutional issues. Thus, it is implied that land is one type of property that must be regulated in terms of ownership, cultivation, and distribution by the state in order to achieve fairness, prosperity, and welfare for all citizens.

\section{Principles of Islamic economy and law}

Along with the development of human life, the need for land is arising because of the increase of activities and human population. However, problems arise when the availability of land is limited and stuck. The ideal ratio between the availability of land and the need to fulfill livelihoods and human life tends to be imbalanced (Yamin and Lubis, 2004: 26). Abu Muhammad al-Hubaisyi, as cited by Sahal Mahfud (2004: 163), states that the main sources of economy are agriculture, industry, and trade. Thus, agriculture as the main source of economy is not separable from land issues.

In the above context, there are several principles of Islamic economic law that can be guided by the state when regulating land issues. Those principles are as follow: (1) the principle of la yakun dawlatan bain al-aghniya a, which is the economic principle that requires equity in the distribution of assets; (2) the principle of 'an tarâdbin, which is the principle of transferring ownership rights ofassets carried out voluntarily; (3) the principle of tabâd almanäfi, which is the principle of transferring ownership rights of assets based on benefits; (4) the principle of taka a al-ijtima $\vec{a}$, which is the principle of transferring property based on interests and social solidarity; and (5) the principle of haqq Allah wa haqq al-adamiy, which is the principle of managing assets based on mutual interests, where both individuals and groups can share profits regulated in a state mechanism.

Generally, Islamic economic law can be used as an important element for determining fairness and distribution in economic development. However, to realize effective and efficient economic development fairness, it is important to have a strong law that guarantees 
fairness and certainty. Regarding that matter, it is belived that Islamic law principles able to become the element that support economic fairness. According to Juhaya S. Praja (1996: 14), the principles of the Islamic Law are (1) monotheism (taubid); (2) justice/fairness; (3) freedom; (4) equality (al-musâwât); (5) amar makeruf nabi mungkar; (6) helping each other (al-ta'âwun); (7) discussion; and (8) tolerance (al-tasâmub). Thus, the Islamic economic and law principles specifically can become law principle of muamalah, which contains Islamic agrarian law. In this case, Azhar Basyir (1994: 190-191) states that Islamic principles of muamalah consist of (1) human honor; (2) family and humanity; (3) cooperation in kindness; (4) justice, worthiness, and kindness; (5) gaining more benefits and minimizing harms; (6) freedom and will; and (7) volunteerism. With those principles, a study of agrarian law is dynamic and open to be continuously developed through intellectual works based on the needs and demand of space and time.

\section{Land and ownership rights in Islamic law perspective}

Land (Arabic: al-ardh), according to Islam, can be seen in a multidimensional perspective, namely an economic perspective, a political perspective, a cultural perspective, and a cosmic-religious perspective (Facchini, 2010: 103-129). However, from these four perspectives, Islamic teachings appear to focus more on economic and religious-cosmos matters. However, from these four perspectives, Islamic teachings appear to focus more on economic and religious-cosmos matters. This can be seen, for example, in the perspective of Islamic economics, land is understood as one of the most important production factors, as classification of production factors proposed by Rafiq Yunus al-Misri (1999: 85-86), namely awamil al-intaj al-mustaqillah which consists of al-ardh, al-amal, and al-mâl; and awamil al-intaj al-tabi'ah which consists of al-mukhatirah, and al-zamara. Al-Misri's view can be compared with the classification of production factors according to Mustafa al-Hamshari (1985: 83-90) which divides into binâ al-insân, al-ardh, anwa 'al-milkiyyah, al-amal, al-mawarid, al-tauzi' and al-infâq.

Meanwhile, if viewed from a religious-cosmic perspective, then the earth (land) with all its contents, functions, and contents is essentially the property of God that is mandated to be handled by humans in their capacity as beings. This is stated, for example, in surat al-Nūr 
verse 42 which means, "And belongs to the kingdom of heaven and earth, and to Allah returns (all beings)", Surah al-Hadid verse 2 which means, "He belongs to the kingdom of heaven and earth...", Surah al-Anbiya verse 105 which means, "Surely this earth is intended for salvationous servants", and Surah al-Hadîd verse 7 which means, "And spend part of your wealth that Allah has made you master...". On this basis, it can be said that land in Islam is not only related to horizontal relations between humans, but also related to vertical relations between God and humans.

The explanation above implies that everything that is done by humans, in terms of management of the earth (land), must be good and right, and in accordance with moraltheological guidance (al-Khatib, 1989: 86-87). According to Yasin Ghadly (1994: 19), the verses above have confirmed that the only real owner of the earth (land) is God. Then, thanks to His grace, the right is given to humans to manage and use the earth (land). Furthermore, al-Qurthubi (2006: 130) stated that human rights to land are to manage and use them in a way that is endowed by God. Nevertheless, in addition to management and utilization rights, in Islam there are also known rights to land ownership by humans.

Conceptually, the ownership rights to land in Islam are based on the concept of ownership rights over all property. According to Wahbah Zuhaili (2002: 515-517), the right of human ownership of property, including land, is only relative or majestic because the intrinsic owner is God. In line with this, Ahmad al-Husaini (1952: 34-37) argued that human ownership rights are inheritance that God entrusted to humans. In a different tone, Ali Ashgar Engineer (1990: 104-110) and Abdel Hameed Bashir (2002: 75-91) said that the right of human ownership is limited to the deposit of God, so that every human being must be responsible for his property not only socially-humanistic, but also morally-theologically.

The position of land as the type of property that can be owned, if viewed from the classification of property, it includes the classification of property that is worth (mutaqamnin), and movable (uqār). Mutaqawnim property can be interpreted as property if another person (who does not have property rights) damages it and is against the law, it must replace it. Meanwhile, uqär property is property that cannot be moved from its place of origin (Hamid, 2005: 3-10). Thus, even though the ownership rights in Islam are not actual or essential, every human being is still given the freedom to try something, including land as private property as long as the effort taken does not violate the provisions (Haneef, 2005: 135). 
The freedom of one's ownership rights to property is limited by the freedom of ownership rights of others, so that Islam does not allow monopolistic practices at all in its ownership. In addition, ownership rights in Islam will not be separated from functions and ethical/moral, humanistic, social, and theological dimensions. Based on this and the principles of Islamic law, ownership rights can be divided into three forms. First, the ownership rights of individuals (al-milkiyyah al-khasssah), namely the right of each individual to own property autonomously. Second, communal property rights (al-milkiyyah al-'ammah), namely collective community ownership rights to certain assets. Third, state property rights (al-milkiyyah al-daulab), namely the right of the state as an institution that is mandated by God through the people to manage all property in the public interest (Sadr, 1981: 333-340).

Indeed, the right of ownership in Islamic law is a form of special rights in an effort to avoid the danger of the concept of ownership with capitalist patterns while providing incentives in economic enterprises. At least, there are three basic conditions for upholding ownership rights in Islamic law, which are not in conflict with applicable rules, do not give damage or loss to others, and do not overlap with other people's property rights (Naqvi, 1994: 110). Therefore, the state as the holder of the highest right of ownership and authority has an important role in making legislation by always considering and paying attention to ethical, social, humanistic, and constructing dimensions of the economy without disregarding individual and communal rights (Faqih and Alfaqiih, 2018: 153-160)

\section{Land ownership distribution mechanism in reviewing Islamic law}

In fact, the post-New Order Indonesia government has initiated several programs as a solution to the problem of land, such as improvement of individual smallholdings, private-sector initiation, plantation revitalization, and partnership initiation (Zen, Barlow, Gondowarsito, and McCarthy, 2016: 78-109). However, as explained before, inequality and imbalance in the distribution of land ownership, especially in Indonesia, have become acute and chronic problems that need to be solved immediately. In general, inequality and imbalance in land ownership arise from several factors, including incomplete regulations, non-compliance regulation, land officials who are less responsive to the needs and the amount of land available, less accurate and incomplete data, erroneous land data, limited 
human resources in charge of resolving land cases, erroneous land transactions, acts of applicant rights, and dualism of agency policies in resolving land issues, resulting in overlapping authority (Mudjiono, 2007: 458-473). Based on that fact, this section describes the distribution mechanism of land ownership by tracing the concept of maqsid al-syari'ah and other instruments regulated by Islamic law as a solution to the problem of inequality and imbalance of land ownership and tenure in Indonesia.

\section{Maqāshid al-syari'ah as a basis of fairness in Islamic agrarian law}

In the discourse on the philosophy of Islamic law, one of the basic and important concepts to explore the principle of legal justice is the concept of maqāsid al-syari'ah or maqāshid altasyri (Rahman, Tareq, Yunanda, and Mahdzir, 2017: 357-370). This concept can be used as a supporting instrument to reach the goals that become the target and particular laws to be realized in human life, both in the form of orders and prohibitions. In general, the goal desired by a law is to achieve, to realize, and to maintain the benefits for humans. Benefit is anything that becomes a necessity of life, which is needed, urgent, and useful, as well as able to bring good to fellow human beings. From this goal, a rule formulation is made, "where there is benefit, there is a law of God" (al-Buthi, 1986: 12). Meanwhile, in the perspective of legal philosophy (general), the term benefit can be said as the same as the term social justice (Mas'udi, 1995: 94-99).

Benefit in law means efforts to realize or attract benefits (jalb al-mashâlih) and avoid or reject damage (daf'u al-mafasid). As a substance of the concept of maqäsid al-syarì'ah, benefit depends on the categorization of human needs in their lives. The needs can be categorized based on the priority scale, namely primary needs (dharuriyat), secondary needs (bajiyat), and tertier needs (tabsiniyyat/takmilat/tatimmat) (al-Syatibi, 2003: 4; Abd al-Salam, 1999: 9). The primary need (dharuriyat) is the basic urgent needs that must be fulfilled. This need is considered essential because if it is not fulfilled, it can cause harm or chaos. According to Wael Hallaq (1999: 1-9), dharuriyat needs contain two meanings, namely a need that must be fulfilled or fought for; and all things that hinder the fulfillment of these needs must be eliminated.

The need for hajizat is a need or something to eliminate obstacles met by humans in fulfilling their dharuriyat needs. In this case, hajiyat needs can help human avoid difficulties 
in meeting their dharuriyat needs. However, even though this need is not met, it does not damage the condition of dharuriyat needs. Meanwhile the necessity of tahsiniyat can be defined as things that can improve the fulfillment of dharuriyat and hajiyat needs. The nature of tabsiniyat need is to increase human dignity, especially from aesthetic factors. Thus, the presence of tabsiniyyat needs will beautify, and his absence will not reduce the essence of the other two needs (al-Zuhaili, 1986: 1020-1023).

In addition to the above classification of human needs, experts in Islamic law have also divided these human needs into five basic elements that must be prioritized. The five main elements are maintenance of religion (hifz al-din), maintenance of the soul (al$n a f s)$, maintenance of mind (al-'aqD), maintenance of assets (al-mā̄), and maintenance of offspring (al-nas) (al-Ghazali, 1993: 250). The correlation between human needs, especially dharuriyat, and the five basic elements of life that must be maintained and protected implies that there are things that must be prioritized in the effort to fulfill every human need by considering the benefits.

The description above clarifies that dharuriyat needs must be prioritized over the hajizat and tahsiniyyat needs. In the context of statehood, to fulfill dharuriyat needs that maintain and protect the five basic elements of human life, a set of laws that relies on the values of fairness or benefit. Therefore, the existence of government in a country as well as all laws, regulations, and the issued policies is dharuriyat needs that must be fulfilled.

The fulfillment of benefit or fairness as the main goals of law will always be related to the formulation of problems in the process of implementing the appropriate laws. In formulating legal problems, what needs to be done is to identify the problems, and then determine the method that will be used to solve the problem. One concept that can be used as a method in developing and formulating law that is adaptive to social changes is maqas said syari'ah, assisted by several approaches from other sciences to analyze it.

In general, maqāsid syari ${ }^{3}$ h postulates used in developing and formulating law are (1) laws is formulated to maintain benefits and to reject harm to humans, so that each decision must lead to the benefits, (2) the wider and more general benefit must be prioritized over the narrow and personal benefit, and (3) the benefit as the soul of a law must be formulated together by the people and the government through discussion with experts in determining the scale 
of priorities. Thus, it can be concluded that benefit, or fairness is the soul and fundamental substance of legal construction. Through the concept of maqâsid shariah, there will be a law that prioritizes the humanist side of humans, both as subject and object of law.

Based on the above explanation, the human need of land is included in the category of primary or dharuriyat needs because land is the most important factor of production that is also related to various aspects, dimensions, and other functions of life. This is in line with what is said by Nejatullah Siddiqi (1981: 261) that food, clothing, and land are basic needs for survival. Thus, when the need for land is not met, it is feared that there will be social inequality, poverty, and unemployment. Furthermore, the exploitation and monopolization of land by certain people can lead to a multidimensional crisis in ecology, food, and energy, which results in the degradation of the quality of the environment.

The fulfillment of the need for land can preserve and protect at least two of the five basic elements of human life, namely the soul (al-nafs) and the assets (al-māt). Protection of the soul includes protection of human rights or specifically land ownership rights. All regulations related to these rights must be formulated based on fairness, benefit, and maintenance of the human soul in general. Thus, it can be said that the solution of various land cases must be carried out within the framework of fairness, benefit, and maintenance of the soul, so that there should be no anarchic acts, violence, and terror to eliminate one's life since everyone has the right to a decent life.

Meanwhile, the protection of assets includes social assistance, economic development, and even distribution of land ownership. Furthermore, it is important to consider environmental protection, such as forest conservation, illegal logging, illegal land clearing, and so on (Alisjahbana and Busch, 2017: 111-136). In this case, the state must take a part in the form of the issuance of laws and regulations that aim to increase the quantity and quality of production and minimize the enviromental damages (Naylor, Higgins, Edwards and Falcon, 2019: 1-14). For example, in agriculture sector, the state must totally invest its capital, in the form of intensification such as providing superior seeds, pest control, and modern production equipment. Thus, there is no land that fails to harvest or land in the form of extensification form, such as implementing strict program of land reform or agrarian reform. Thus, there are no peoplewith land to be used as a source of production. 
Based on the formulation and identification of the agrarian issues as explained previously, the government that has the highest authority in a country must make such a way as to limit the ownership rights of a person or group through legislative procedures in the form of legislation. The law, as a product of legislation, is a form of social contract to guarantee fairness and legal certainty. Nevertheless, it is important to note that the legal action of the state is not merely making a legal order, but implementing the legal order, so that the two sides of the state, as an institution and a legal instrument can serve and manage the interests of the people. Therefore, every regulation and policy taken by the government must rely on the principle of benefit, be oriented to the protection of the life of every citizen (bifz, al-nafs), and have an insight of the development of economic equality (bifz, al-māal).

\section{The role of state in distribution and revocation of land ownership}

Throughout the history of human life, land has a strategic meaning, and it is included in dharuriyat (basic) needs as a source of human survival. Almost all aspects of human life depend on and come from the land as agricultural land, settlements, businesses, and places of worship. Therefore, land can support the fulfillment of human rights. In Koran, it is written in Surah Thaha verse 20, namely,

"(God) has made this earth a place for you, and made paths on it for you, and sent water (rain) from the sky. Then, We grow it with (rain water) various types of plants."

Fakhrudin al-Razi (1980: 68), responding to the verse above, states that the purpose of God creating the earth as a place is for humans and all creatures in general to do their activities, either sitting, standing, sleeping, planting, or other useful things. That way, land must be distributed fairly so that it can be used productively to meet the needs of human life. Regarding to this matter, the normative basis of Islam clarifies that the distribution of assets, including land, should not be centered in certain people or groups. It is written in Surah Al-Hasyr verse 7, which means, "And what Allah restored to His Messenger from the people of the towns - it is for Allah and for the Messenger and for [his] near relatives and orphans and the [stranded] traveler - so that it will not be a perpetual distribution among the rich from among you..."

According to Wahbah al-Zuhaili (1991: 81), the understanding of the above verse is that 
the treasure $f a \imath$ is not only intended and distributed to leaders, rich people, and strong people among humans, but also the poor people. This is the principle of the obligation to fulfill needs and to use wealth for all humans. Therefore, a leader, in the context of the government (state), must distribute land in accordance with one's willingness and ability to use and to manage it. In the current context, the existence of a state has made land an integral part of the state, resulting in giving authority to the state to compose the legal system and the designation of land ownership, tenure, and use through fair distribution for the greatest prosperity and welfare of the people. Moreover, the important role of the state in the fairness of the distribution of land ownership is to issue regulation and policy based on the benefits or fairness for all people. This is in line with the rule of "tasharruf al-imām 'al-ra'iyyat manüthun bi al-maslahah" (the policies made by the leader/president/king/sultan to his people should refer to the benefits), and "waliyy al-amr ma 'mür bi murärät al-maslahah" (the policies made by the rulers/state/government should always refer to the benefits) (al-Suyuthi, 1982: 121).

In Islamic law, the mechanism of fair distribution and redistribution of land is known as iqth $\vec{a}$. Simply, iqth $\vec{a}$ can be interpreted as a gift land. According to al-Syaukani (t.t.: 311), $i q t h \hat{a}$ is a government decree concerning on land distribution to someone who is capable of cultivating the land, both as ownership rights and utilization rights. Meanwhile, according to Badruddin al-'Aini (2001: 119), iqthà is the action of giving something from God's wealth done by the leader (state) to people who deserve it, and it is generally applied in the context of land distribution by giving a part of the occupied land to the parties who deserve it.

Based on Islamic Law, the distribution of land belongs to people who are able to manage the land in order to improve their living conditions, as well as people who work as community servants, so that they cannot manage it themselves. In this context, the state can take two forms of the distribution of land to its people. First, giving the ownership rights of a part of the land that is controlled by the state to parties that deserve to manage it. Second is giving the management rights only in certain period. Thus, it can be said that the distribution of land can be classified into two, namely ownership rights (iqthä tamlike) and utilization/management rights (iqthä' ghairu tamlik).

The authority of the government in giving land to the people must always be followed by several considerations, especially consideration of the willingness and ability to manage, 
and the principle of fairness. If someone just wants to own a piece of land without being able to manage it productively, then it will take other's rights to get the shared rightsamong them. Thus, it is feared that it can cause inequality among the people. In fact, Islam is antiinequality. This anti-inequality attitude is a reflection of hif̧̨h al-nafs and hif̧̧ al-mäl, which is part of maqassid al-syari'ah because one part of hif:̧h al-nafs is a decent life, while one part of hifžb al-mäl is economic balance (al-tawäzun al-iqtishäd).

The provision of Islamic law regarding land ownership is that land must be continuously managed and utilized. Thus, land ownership in Islam does not follow the system of feudalism because the system of ownership or tenure of feudal land is contrary to the principle of equitable distribution of assets and prevents the proper use of land. Meanwhile, unused land is a waste (Mannan, 1986: 79). In the case when someone who has a large land, whether it is given by the state or not, but cannot use it productively, the state has the right to take action to the owner so that the land can be utilized properly. When the owner who has the right over the land abandones and does not cultivateit for three years continuously, the owner no longer has the rights, and the state is able to revoke the ownership rights and to give the land to someone else who can manage it. Furthermore, the state is also allowed to cancel the policies of the previous government which has given land to the conglomerates in consideration of the benefits for public, namely to avoid the emergence of more negative impactsthat prioritize benefits for certain party or individual (al-Suyuthi: 1982: 104).

In the above context, the state must avoid the imbalance of ownership and tenure overthe land among various elements of the state. As we know, based on the fact grown in Indonesia, there are certain parties, such as conglomerates/corporations that own and control million hectares of land. On the other side, there is middle to lower class community, such as farmers, who does not own land at all. Therefore, the state is allowed to reacquire the land, within certain limits by force, and the land is then given to those who need it more.

\section{Conclusion}

According to the description above, it can be concluded that the main problem of the inequality of ownership, tenure, and use of land in Indonesia, which has leads to various land cases, is not just about the substance or material of legal-formal rules and policies, but 
also the basic concepts, philosophy, and orientation about the distribution of the land itself. This is evidenced by the inconsistency between the mandate and the goals of the 1945 Constitution and the 1960 Basic Agrarian Law with the elaboration in the Constitution of Implementation, and between all legislations and their implementation in the field. Thus, a fundamental and comprehensive legal protection is needed, but flexible in its implementation to ensure the legal certainty for land distribution policies.

In the view of Islamic law, land is defined as the basic human need and has various functions, such as economic function and social function. Philosophically, the intrinsic owner of land is God, which is then mandated to the state to be regulated in such a way in terms of ownership, management, and utilization for the sake of welfare and shared prosperity. Therefore, the state is responsible for realizing the distribution of land fairly and evenly through the mechanism of legislation.

Islamic law, as one of the legal systems in Indonesia, has offered the principles of maqāsid al-syariah concept to be used as a basic concept and philosophical foundation for every policy on land. Specifically, the principles related to the agrarian sector in Indonesia are the principle of benefit or social justice, the principle of life preservation, and the principle of assets preservation. By considering the principle of benefit as the basic concept of land law, it is possible to create a law that puts the humanist side on the first place, both as a subject and as an object of law. The principle of caring for the life will preserve the existence of human rights in the form of the rights to get a decent life. Meanwhile, the principle of preserving assets will lead to equity and economic balance among the people.

To overcome inequality of land ownership in Indonesia, the state has the authority to share or to give the land rights as well as revoke the ownership, management, and use rights of the land, from both individuals and corporation. Practically, the steps taken by the state can be done by revoking the excess land rights, both neglected land and inappropriate-used land. Then, the land is given to those who want to and are able to manage, and those who need it; and limiting land rights, both in terms of land size and time period. In order to make this land distribution and redistribution process effective and efficient, the state is also required to provide various incentives. Thus, every citizen is able to manage and to utilize the land independently. 
Ijtihad: Jurnal Wacana Hukum Islam dan Kemanusiaan, Volume 20, No. 2, Desember 2020: 211-234

\section{Bibliography}

Abd al-Salam, Izzuddin ibn. Qawaid al-Ahkām fi Mașālih al-Anām. Beirut: Dār al-Ma'rifah, 1999.

Abu Hanifah. al-Durr al-Mukhtār, jilid IV. Beirut: Dār al-Fikr, 1966.

Ahida, Rida. Keadilan Multikultural. Jakarta: Ciputat Press, 2008.

Ahmad, Mahfooz. "Distributive Justice and Fiscal and Monetary Economics in Islam", in Mohammad Ariff (ed). Monetary and Fiscal Economics of Islam. Jeddah: International Centre for Research in Islamic Economics King Abdulaziz University, 1982.

al-`Aini, Badruddin. 'Umdah al-Qāri, jilid XV. Beirut: Dār al-Kutub al-'Ilmiyyah, 2001.

Alisjahbana, Armida S. and Jonah M. Busch. "Forestry, Forest Fire and Climate Change in Indonesia", in Bulletin of Indonesian Economic Studies Vol. 53, No. 2 (2017): p. 111-136. al-Ashfahani, Ragib. Mu’jam Mufradāt li Alfā̧̧̄ al-Qurān. Kairo: Dār al-Kutub al- 'Ilmiyyah, 2004.

Auda, Jasser. Maqasid al-Shariah as Philosophy of Islamic Law: A Systems Approach. London: The International Institute of Islamic Thought, 2008.

Azizy, A. Qodri. Eklektisisme Hukum Nasional: Kompetisi Antara Hukum Islam dan Hukum Umum. Yogyakarta: Gama Media, 2004.

Bashir, Abdel Hameed M. "Property Rights, Institution and Economic Development: In Islamic Perspective", in Humanumics Vol. 18, No. 3 (2002): p. 75-91.

Basyir, Ahmad Azhar. Refleksi atas Persoalan Keislaman Seputar Filsafat, Hukum, Politik, dan Ekonomi. Bandung: Mizan, 1994.

Bedner, Adrian. "Indonesian Land Law: Integration at Last? And for Whom?”, in John F. McCarthy and Kathryn Robinson (eds). Land and Development in Indonesia Searching for the People's Sovereignty. Singapura: ISEAS-Yusof Ishak Institute, 2016.

al-Buthi, Muhammad Sa'id Ramadhan. Dhawābit al-Maslahah fi Syarỉah al-Islämiyah. Beirut: Mu'assasah al-Risālah, 1986.

Engineer, Ashgar Ali. Islam and Liberation Theology: Essays on Liberative Elements in Islam. New Delhi: Stosius Inc/Advent Books Division, 1990.

Facchini, Francois, "Religion, Law and Development: Islam and Christianity-Why is it in Occident and Not in the Orient that Man Invented the Institutions of Freedom?”, in 
Fairness in the distribution of land ownership in Indonesia ... (Koko Komaruddin)

European Journal of Law and Economics Vol. 29, No. 1 (2010): p. 103-129.

Faqih, Aunur Rohim and Abdurrahman Alfaqiih. "The Existence of Maslahah in the Establishment and Holding of State Owned Enterprises in Indonesia," in Journal of Arts, Science \& Commerce Vol. 9, No. 2 (2018): p. 153-160.

Ghadiy, Yasin. al-Amwāl wa al-Amläk al- 'Ámmah fi al-Islām. Baghdad: Muassasah Ram, 1994. al-Ghazali, Abu Hamid Muhammad ibn Muhammad. al-Mustasfä min Ilm al-Ushūl. Beirut: Dār al-Kutub al-'Ilmiyyah, 1993.

Hallaq, Wael B. A History of Islamic Legal Theories: An Introduction to Sunni Usul al-Fiqh. Cambridge: Cambridge University Press, 1999.

Hamid, Zahra. Harta dan Milik dalam Hukum Islam. Yogyakarta: Bina Usaha, 2005.

al-Hamshari, Mustafa. al-Nǐ̌hăm al-Iqtișādi fi al-Islām. Riyadh: Dār al-Ulum, 1985.

Haneef, Sayed Sikandar. Ethics and Fiqh for Daily Life: An Islamic Outline. Kuala Lumpur: International Islamic University Malaysia, 2005.

al-Husaini, Abu Nasr Ahmad. al-Milkiyyāt fi al-Islām. Kairo: Dār al-Kutub al-Harbisah, 1952. Ichtijanto, H. "Pengembangan Teori Berlakunya Hukum Islam di Indonesia", in Eddi Rudiana Arif (ed). Hukum Islam di Indonesia: Perkembangan dan Pembentukan. Bandung: Remaja Rosdakarya, 1991.

Jaelani, Aan. "Economic Philosophy of al-Mawardi: Economic Behavior in Adab al-Dunya wa-al-Din and al-Ahkam al-Sulthaniyah", in MPRA Paper 70339 (2016): p. 1-28.

Khadduri, Majid. The Islamic Conception of Justice. Baltimore, Maryland: The Johns Hopkins University Press, 1984.

al-Khatib, Muhammad Ibrahim. al-Niz̧̧̄om al-Iqtisādi fi al-Islām. Riyādh: Maktabāt Haramain, 1989.

Mahasari, Jamaluddin. Pertanahan dalam Hukum Islam. Yogyakarta: Gama Media, 2008.

Mahfud, Sahal. Nuansa Fiqh Sosial. Yogyakarta: LkiS, 2004.

Mannan, Muhammad Abdul. Islamic Economics: Theory and Practice. Sevenoaks: Hodder and Stoughton, 1986.

Mas'udi, Masdar F. “Meletakkan Kembali Maslahat Sebagai Acuan Syari'ah”, Jurnal Ilmu dan Kebudayaan Ulumul Qur'an, Vol. 6, No. 3 (1995): p. 94-99. 
Ijtihad: Jurnal Wacana Hukum Islam dan Kemanusiaan, Volume 20, No. 2, Desember 2020: 211-234

Mudjiono. "Alternatif Penyelesaian Sengketa Pertanahan di Indonesia Melalui Revitalisasi Fungsi Badan Peradilan," Jurnal Hukum Vol. 14, No. 3 (2007): p. 458-473.

al-Misri, Rafiq Yunus. Ushūl al-Iqtișād al-Islāmiy. Damaskus: Dār al-Qalām, 1999.

Muthahhari, Murtadha. Keadilan Asas Pandangan-Dunia Islam, trans. Agus Efendi. Bandung: Mizan, 2009.

Naqvi, Syed Nawab Haidar. Islam, Economics and Society. London: Kegan Paul International, 1994.

Naylor, Rosamond L., Mattew M. Higgins, Ryan B. Edwards, and Walter P. Falcon. "Decentralization and the Environment: Assesing Smallholder Oil Palm Development in Indonesia”, Ambio Vol. 48. (2019): p. 1-14.

Neilson, Jeff. "Agrarian Transformation and Land Reform in Indonesia", in John F. McCarthy and Kathryn Robinson (eds). Land and Development in Indonesia Searching for the People's Sovereignty. Singapura: ISEAS-Yusof Ishak Institute, 2016.

Nugroho Arief. "Islamic Economic Thought Abu Ubaid (154-224 H): Current Functions of Money and Relevance," MPRA Paper, Vol...., No.... (2018): p. 1-6.

Nurjannah. "Undang-undang Pokok Agraria (UUPA) Sebagai Induk Landreform”, AlDaulah Vol. 3, No. 2 (2014): p. 193-205.

Praja, Juhaya S. Filsafat Hukum Islam. Bandung: UNISBA Press, 1996.

Qardhawi, Yusuf. Fiqh Maqāsid Syariah. Jakarta: Pustaka al-Kautsar, 2007.

al-Qurthubi, Abu Abdullah. al-jāmi’ li Ahkām al-Qurān, juz I. Beirut: Muassasāt al-Risālah, 2006.

Rachman, Noer Fauzi and Usep Setiawan (eds). Reforma Agraria untuk Mewujudkan Kemandirian Bangsa. Jakarta: Konsorsium Pembaruan Agraria, 2015.

Rahman, Faried Kurnia, Mohammad Ali Tareq, Rochania Ayu Yunanda, and Akbariah Mahdzir, "Maqāșid al-Syarî'ah-Based Performance Measurement for the Halal Industry", Humanomics Vol. 33, No. 3 (2017): p. 357-370.

al-Razi, Fakhruddin. Mafätih al-Ghäib. Beirut: Dār al-Fikr, 1980.

Sadr, Muhammad Baqr. Iqtișādunā. Beirut: Dār al-Ta’ūif li al-Maṭuāt, 1981.

Shihab, Quraish. Wawasan Islam. Bandung: Mizan, 1996.

Shohibuddin, Mohamad, "Understanding and Overcoming the Problem of Agrarian 
Fairness in the distribution of land ownership in Indonesia ... (Koko Komaruddin)

Inequality", Bhumi Vol. 5, No. 1 (2019): p. 1-12.

Siddiqi, M. Nejatullah. "The Guarantee of a Minimum Level of Living in Islamic State; Distributive Justice and Need Fulfilment in an Islamic Economy", in Munawar Iqbal (ed.). Distributive Justice and Need Fulfillment in an Islamic Economy. Leicester: The Islamic Foundation, (1988).

Simanjuntak, Enrico. "Esensi Sengketa Administrasi Pertanahan di Peradilan Tata Usaha Negara”, Bhumi Vol. 3, No. 2 (2017): p. 171-188.

Stewart, Frances. "Horizontal Inequalities: A Neglected Dimension of Development", in Anthony F. Shorrocks (ed). Wider Perspective on Global Development. Basingstoke: Palgrave Macmillan, 2005.

Suryadi, Budi. Sosiologi Politik: Sejarah, Definisi, dan Perkembangan Konsep. Yogyakarta: IRCiSod, 2007.

al-Suyuthi, Jalaluddin. al-Asybāh wa an-Naz̧āir. Beirut: Dār al-Kutub al-'Ilmiyyah, 1983.

Syarief, Elza. Menuntaskan Sengketa Tanah Melalui Pengadilan Khusus Pertanahan. Jakarta: Gramedia, 2012.

al-Syaukani, Muhammad ibn Ali ibn Muhammad. Nayl al-Authār, jilid V. Beirut: Dār alKutub al-'Ilmiyyah, tt.

al-Syatibi, Abu Ishaq. al-Muwäfaqāt fi Ușül al-Syarỉah. Kairo: Mustafa Muhammad, 2003.

Taha, Ghani Hasun. Haqq al-Milkiyyah. Kuwait: al-Jami’ah al-Kuwait, 1977.

Tasmara, Toto. Spiritual Centered Leadership: Kepemimpinan Berbasis Spiritual. Depok: Gema Insani Press, 2001.

Yamin, Muhammad and Abd. Rahim Lubis. Beberapa Masalah Aktual Hukum Agraria. Medan: Pustaka Bangsa Press, 2004.

"The Future of Land Ownership Regulation in Indonesia," International Journal of Multicultural and Multireligious Understanding Vol. 6, No. 6 (2019): p. 712-720.

Zen, Zahari, Colin Barlow, Ria Gondowarsito, and John F. McCarthy, "Interventions to Promote Smallholder Oil Palm and Socio-economic Improvement in Indonesia", in Cramb, Rob and John F. McCarthy (eds.). The Oil Palm Complex: Smallholders, Agribusiness and the State in Indonesia and Malaysia (cetak miring). Singapore: NUS Press, 2005 
Ijtihad: Jurnal Wacana Hukum Islam dan Kemanusiaan, Volume 20, No. 2, Desember 2020: 211-234

al-Zuhaili, Wahbah. Ușül al-Fiqh al-Islāmiy. Beirut: Dār al-Fikr, 1986.

al-Zuhaili, Wahbah. al-Tafsir al-Munir fi al- 'Aqidah wa al-Syarì'ah wa al-Manhäj, jilid IX. Beirut: Dār al-Fikr, 1991.

al-Zuhaili, Wahbah. al-Fiqh al-Islämiy wa Adillatubu. Beirut: Dār al-Fikr, 2002. 